\title{
Suppressive effect of non-anaphylactogenic anti-IgE antibody on the development of dextran sulfate sodium-induced colitis
}

\author{
OK-HWA KANG ${ }^{1 *}$, DAE-KI KIM ${ }^{2 *}$, YEON-A CHOI ${ }^{1}$, HYE-JUNG PARK $^{1}$, JIN TAE $^{1}$, CHON-SIK KANG $^{2}$, \\ SUCK-CHEI CHOI ${ }^{3}$, YONG-HO NAH ${ }^{3}$, HERN-KU LEE ${ }^{2}$ and YOUNG-MI LEE ${ }^{1}$ \\ ${ }^{1}$ Department of Oriental Pharmacy, College of Pharmacy, Wonkwang University, Iksan, Jeonbuk 570-749, \\ ${ }^{2}$ Department of Immunology, Chonbuk National University Medical School, Jeonju, Jeonbuk 561-182, \\ ${ }^{3}$ Department of Internal Medicine and Institute of Digestive Disease, Wonkwang University \\ School of Medicine, Iksan, Jeonbuk 570-749, Korea
}

Received May 30, 2006; Accepted July 20, 2006

\begin{abstract}
Inflammatory bowel disease (IBD) is a spectrum of immune-mediated chronic disorders of the intestine. Patients with IBD tend to exhibit significantly elevated levels of $\mathrm{IgE}$ in their serum. In general, the pathogenesis of IBD exhibits inflammatory events such as immunoglobulin E (IgE)-mediated hypersensitivity. We examined the effect of the non-anaphylactogenic anti-IgE antibody, which has been known to block IgE functions, in an animal model of ulcerative colitis induced by the oral intake of dextran sulfate sodium (DSS) for seven days. The non-anaphylactogenic anti-IgE antibody was subcutaneously injected on day 0 of DSS treatment. The disease activity index (DAI) was calculated by scoring intestinal states, including body weight loss, diarrhea, and rectal bleeding, and the activities of myeloperoxidase (MPO) and chymase were measured in the colon tissue. In addition, the expression of tumor necrosis factor (TNF)- $\alpha$ and cyclooxygenase (COX)-2 was determined by Western blotting. Administration of the anti-IgE antibody markedly reduced the histological damage to the colon and the DAI increment exhibited by the DSS-induced colitis. The anti-IgE antibody also significantly suppressed the activities of MPO and chymase as well as the expression of TNF- $\alpha$ and COX-2 in the DSS-treated colon tissue. Furthermore, the elevation of IgE levels in serum was induced by DSS and
\end{abstract}

Correspondence to: Dr Young-Mi Lee, Department of Oriental Pharmacy, College of Pharmacy, Wonkwang University, Iksan, Jeonbuk 570-749, Korea

E-mail: ymlee@wonkwang.ac.kr

*Contributed equally

Abbreviations: IBD, inflammatory bowel disease; DSS, dextran sulfate sodium; UC, ulcerative colitis; $\mathrm{CD}$, Crohn's disease; IgE, immunoglobulin E; TNF, tumor necrosis factor; MPO, myeloperoxidase; COX, cyclooxygenase; DAI, disease activity index

Key words: non-anaphylactogenic anti-IgE antibody, inflammatory bowel disease, dextran sodium sulfate, ulcerative colitis reduced by anti-IgE antibody injection. Thus, these results indicate that the IgE response played an important role in the clinical signs and the expression of inflammatory mediators in a colitis model caused by DSS treatment, suggesting that the non-anaphylactogenic anti-IgE antibody may be a useful therapeutic agent for ulcerative colitis.

\section{Introduction}

Inflammatory bowel disease (IBD) is a spectrum of immunemediated chronic gastrointestinal disorders, including ulcerative colitis (UC) and Crohn's disease (CD). The pathogenesis of IBD is believed to result from the interaction of genetic, immune, and environmental factors (1-3). UC and $\mathrm{CD}$ are associated with intestinal and extra-intestinal manifestations, which comprise weight loss, diarrhea accompanied with blood and mucus, fever, gastric dysmotility, and shortening of the colon (4). UC exhibits a pathological state primarily affecting the superficial layer of the colon mucosa, and the histological analysis of UC patient tissue shows general features, such as ulceration of the mucosa, blunting and loss of crypts, and infiltration of inflammatory cells (5). However, the pathogenesis of UC is unknown. Disruption of immune systems in the intestinal tract has been suggested to be involved in the etiology of UC. Prolonged and chronic UC may progress to colorectal cancer (6). The conventional treatment of IBD includes aminosalicylates, corticosteroids, and immunosuppressive drugs. However, they have a slow onset of action and many patients do not respond to long-term use. For the treatment of IBD, current studies are thus focusing on the development of new biological therapies, selectively blocking the inflammatory cascade with new drugs such as immunomodulating agents and antiinflammatory cytokines $(7,8)$.

Immunoglobulin $\mathrm{E}$ (IgE) is known to play an important role in inflammatory reactions. A complex of IgE and specific antigen causes the activation of mast cells through crosslinking to high affinity IgE receptor. IgE-mediated mast cell degranulation is involved not only in immediate hypersensitivity but also in the elicitation of delayed-type hypersensitivity including IBD, which is characterized by $\mathrm{T}$ cell-driven inflammatory cell infiltration. In the gastro- 
intestinal tract, an increased number of mast cells were observed in patients with UC and CD (9). Mast cell-derived mediators, such as tryptase and TNF- $\alpha$, secreted by mast cell activation were significantly elevated in UC tissue $(10,11)$. In a previous study, we also observed that tryptase-positive mast cells expressed protease-activated receptor (PAR) and TNF- $\alpha$ in UC patient tissues (12). Interestingly, most IBD patients, particularly with UC, showed prevalent allergic symptoms and high serum $\operatorname{IgE}$ levels (13). Moreover, an $\operatorname{IgE}$ response in the intestine was observed during infection with $T$. spiralis, $H$. polygyrus and Strongyloides venezuelensis in rats (14). These studies indicate that IgE-dependent mechanisms may be involved in the pathogenesis of IBD as well as the protective immunity that develops against individual gastrointestinal nematodes.

Recently, therapeutic anti-IgE antibodies have been developed to reduce free IgE levels and to block the binding of $\operatorname{IgE}$ to FceRI without crosslinking $\operatorname{IgE}$ and subsequently triggering degranulation of IgE-sensitized cells. The nonanaphylactogenic anti-IgE monoclonal antibody is able to bind the specific site of IgE recognizing IgE receptors, FceRI and FceRII. It presumably recognizes an epitope within the FceRI-binding region of $\mathrm{IgE}$ and does not induce degranulation in IgE-sensitized mast cells. As a result of this binding specificity, the antibody was termed the nonanaphylactogenic antibody $(15,16)$. These antibodies inhibit the functions of IgE-effector cells by blocking IgE binding to IgE receptors without cell activation because it cannot bind to $\operatorname{IgE}$ on cell surfaces where the FceRI receptor has already masked the anti-IgE epitope.

Dextran sodium sulfate (DSS)-induced colitis in mice described by Okayasu et al has a phenotype similar to human acute and chronic UC (17). Tissue injury in DSS-induced colitis is associated with histological changes including crypt shortening, progressing to crypt dropout, patchy mucosal inflammation, and erosion of the epithelium (1). In the present study, we evaluated the potential use of a non-anaphylactogenic anti-IgE antibody as a new therapeutic drug for the treatment of IBD, particularly UC. Using an animal model of DSS-induced colitis, we examined the involvement of $\operatorname{IgE}$ response and the inhibitory effects of non-anaphylactogenic anti-IgE antibody in the pathogenesis of colitis.

\section{Materials and methods}

Animals and reagents. Female BALB/c mice (7 weeks old) were obtained from the SamTaco animal facility (Gyeonggi, Korea). Mice were housed in a specific pathogen-free environment for at least 1 week for adaptation to the environmental changes and were sacrificed by $\mathrm{CO}_{2}$ inhalation at the end of the study. DSS (mol wt; 36,000-50,000) was purchased from ICN Biomedicals (Aurora, OH). Purified anti-mouse IgE $\mathrm{mAb}(\mathrm{R} 35-92)$ and control IgG1 were from BD-Pharmingen (San Diego, CA). The specific antibodies against TNF- $\alpha$ and COX-2 were from Santa Cruz Biotechnology (Santa Cruz, CA). All chemical reagents were from Sigma Co. (St. Louis, MO).

Induction of colitis by DSS. Acute colitis in mice was induced by providing drinking water ad libitum containing $5 \%(\mathrm{w} / \mathrm{v})$ DSS for 7 days. Mice were checked daily for loss of body weight, stool consistency and the presence of gross bleeding. Mice were randomized into groups receiving anti-IgE antibody $(5 \mu \mathrm{g} / \mathrm{kg}$ or $50 \mu \mathrm{g} / \mathrm{kg})$, rat control $\operatorname{IgG}(50 \mu \mathrm{g} / \mathrm{kg})$, or saline as a negative control. Antibodies diluted with saline $(50 \mu \mathrm{l})$ were subcutaneously injected only once on day 0 of DSS treatment. Mice finally were sacrificed and assessed after DSS treatment for 7 days.

Disease activity index (DAI). The disease activity index (DAI) was derived by scoring three major clinical signs, which were weight loss, diarrhea, and rectal bleeding, 7 days after DSS administration as described by Murthy et al (18). Loss of body weight was calculated as the difference between the initial and actual weight. Diarrhea was showed as mucus/fecal material adherent to anal fur. The presence or absence of diarrhea was confirmed by examination of the colon following completion of the experiment. Mice were sacrificed and the colons were excised from the animals. Diarrhea was defined by the absence of fecal pellet formation in the colon and the presence of continuous fluid fecal material in the colon. Rectal bleeding was defined as diarrhea containing visible blood and gross rectal bleeding and scored as described for diarrhea.

Three major clinical signs (weight loss, diarrhea, and occult/gross bleeding) were scored separately as shown in Table I. The DAI was calculated from the score of the clinical signs using the following formula: DAI=(weight loss score) $+($ diarrhea score $)+($ rectal bleeding score $)$. The clinical parameters used here are comprehensive functional measures that are analogous to the subjective clinical symptoms observed in human ulcerative colitis. This method of scoring has been validated by repeated studies. It correlates well with histological healing measured as crypt scores. A significant decrease in the DAI $\left({ }^{*} \mathrm{p}<0.05\right)$ is considered an end-point of successful therapy.

Histochemical staining. The distal colons were removed immediately from the mice after euthanasia. The length of colon was measured and the feces were carefully removed from the GI tract lumen. Colon tissue was fixed in $4 \%$ buffered paraformaldehyde ( $\mathrm{pH} 7.0)$, embedded in paraffin, and sectioned $(6-\mu \mathrm{m})$ onto gelatin-coated glass slides. After deparaffinization with xylene and rehydration through gradual ethanol washes $(100 \%, 90 \%, 80 \%, 70 \%$, and $0 \%)$, sections were stained with hematoxylin and eosin (H\&E). All specimens were visualized and photographed under a microscope using a camera system (Olympus LK2, Japan).

Myeloperoxidase activity assay. Myeloperoxidase (MPO) has been known to be a marker for the detection of neutrophil infiltration in intestinal inflammation (19). The samples of colon were homogenized in $20 \mathrm{mM}$ phosphate buffer ( $\mathrm{pH}$ 7.4) for $30 \mathrm{sec}$ and centrifuged at $15,000 \mathrm{x}$ g for $20 \mathrm{~min}$. The pellet was re-homogenized in 10 volumes of $50 \mathrm{mM}$ potassium phosphate buffer ( $\mathrm{pH} 6.0$ ) containing $0.5 \%$ hexadecyltrimethyl ammonium bromide (HTAB, Sigma, St. Louis, MO) and $10 \mathrm{mM}$ EDTA on an ice bath. The homogenate was then freeze-thawed once, sonicated for $1 \mathrm{~min}$ and centrifuged at $15,000 \times \mathrm{g}$ for $20 \mathrm{~min}$. For the assay of myeloperoxidase activity, $50 \mu 1$ of supernatants was added to the wells of a 96- 
Table I. Scoring of clinical signs for the disease activity index.

\begin{tabular}{lccc}
\hline Score & Weight loss $(\%)$ & Diarrhea & Occult/gross bleeding \\
\hline 0 & None & None & Normal \\
1 & $1-5$ & Mild & Occult \\
2 & $5-10$ & & Gross bleeding \\
3 & $11-15$ & Severe watery & \\
4
\end{tabular}

Disease activity index is the mean of individually combined scores of weight loss, diarrhea and bleeding.

well plate and mixed with $50 \mu 1$ of $50 \mathrm{mM}$ phosphate buffer (pH 6.0) containing $0.5 \% \mathrm{HTAB}, 50 \mu \mathrm{l}$ of o-dianisidine $(0.68$ $\mathrm{mg} / \mathrm{ml}$ in distilled water), and $0.3 \mathrm{mM}$ hydrogen peroxide to initiate the reaction. The complete reaction mixture was incubated for $3 \mathrm{~min}$ at $37^{\circ} \mathrm{C}$ and the change in absorbance was measured spectrophotometrically at $450 \mathrm{~nm}$. Pure human MPO (Sigma) was used as a standard. The inhibition percentage of MPO activity was calculated using the following equation:

$$
\text { Inhibition }(\%)=\frac{(A-B)}{A} \times 100
$$

where A and B are the myeloperoxidase activity in DSSinduced colitis without or with the antibody treatment, respectively.

Chymase activity assay. The distal colon specimens were homogenized in $20 \mathrm{mM}$ Na-phosphate buffer ( $\mathrm{pH} \mathrm{7.4)} \mathrm{and}$ then centrifuged at $15,000 \mathrm{x}$ g for $30 \mathrm{~min}$. The supernatant, which was rich in non-chymase proteases that would interfere with the assay, was discarded and the pellets were homogenized in 5 volumes (w/v) of $10 \mathrm{mM} \mathrm{Na-phosphate}$ buffer (pH 7.4) containing $2 \mathrm{M} \mathrm{KCl}$ and $0.1 \%$ polyoxyethylene octylphenyl ether, stored overnight at $4{ }^{\circ} \mathrm{C}$, and then centrifuged at $15,000 \mathrm{x} \mathrm{g}$ for $30 \mathrm{~min}$. The supernatants were used as the extract containing chymase (20). The enzyme activities of chymase were determined using the substrate $0.2 \mathrm{mM}$ N-succinyl-Ala-Ala-Pro-Phe-p-nitroanilide (Sigma) containing $50 \mu \mathrm{g} / \mathrm{ml}$ heparin, $1 \mathrm{mg} / \mathrm{ml}$ bovine serum albumin, $1 \mathrm{mg} / \mathrm{ml}$ aprotinin, $2 \mathrm{M} \mathrm{KCl}$ and $100 \mathrm{mM}$ Tris- $\mathrm{HCl}, \mathrm{pH} 7.6$ (21). In all assays, $50 \mu 1$ of sample was added to a total reaction volume of $200 \mu 1$ in a 96-well plate. This substrate is hydrolyzed by chymase and continuously releases p-nitroaniline, which is a yellow chromophore. Thereby, multiple readings were taken and the reaction rates were measured by continuously monitoring the increase in absorbance at $405 \mathrm{~nm}$ for 5 min using a micro-ELISA reader. The gradient of linear increase of the absorbance (A405/min) was converted into protease activity. Protein concentration was measured using a bicinchoninic acid (BCA) protein assay reagent (Sigma) and the chymase activity was shown as the specific activity (mU/mg protein).

Western blot analysis. The distal colons (100 mg) were homogenized in $600 \mu \mathrm{l}$ of lysis buffer (iNtRON Biotech, Korea), incubated for $30 \mathrm{~min}$ on ice, and centrifuged at $13,000 \mathrm{rpm}$ for $5 \mathrm{~min}$. The supernatants were transferred to a fresh tube and their protein concentrations were determined using a Pro-measure solution (iNtRON Biotech). Lysates ( $50 \mu \mathrm{g}$ of protein) were separated by $10-15 \%$ SDS-PAGE and transferred to PVDF membranes (Amersham Pharmacia Biotech, Piscataway, NJ). After blocking with 5\% skim milk, the membranes were blotted with the specific antibody
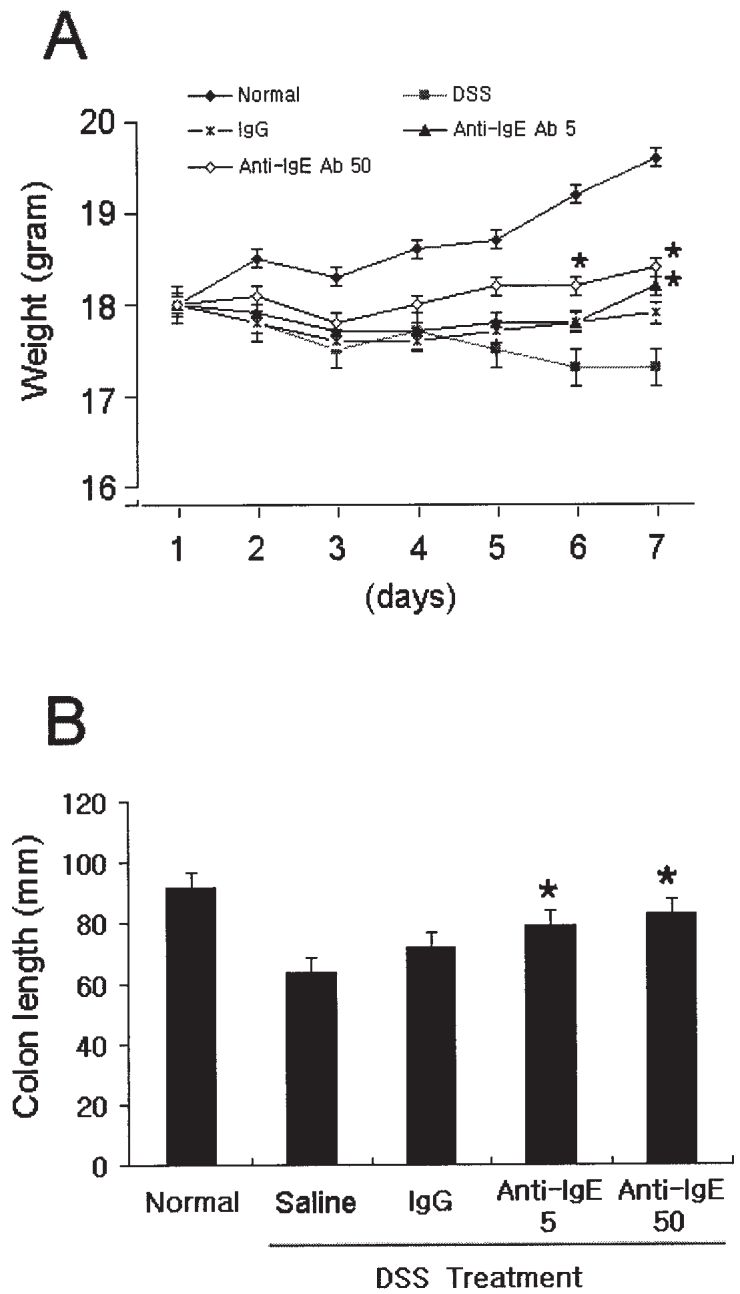

Figure 1. Effect of anti-IgE antibody on weight loss (A) and colon length (B) in DSS-induced colitis. Colitis was induced by oral administration of DSS (5\%) for 7 days and anti-IgE antibody (R35-92) was injected subcutaneously at two different doses, $5 \mu \mathrm{g} / \mathrm{kg}$ and $50 \mu \mathrm{g} / \mathrm{kg}$ body weight. IgG $(50 \mu \mathrm{g} / \mathrm{kg})$ and saline were used as comparative controls. The body weight of mice was measured every day during DSS treatment and colon length of mice was measured at day 7 after DSS treatment. Data are expressed as the mean \pm SEM $\left({ }^{*} \mathrm{p}<0.05\right.$ vs. DSS plus saline $)$. 


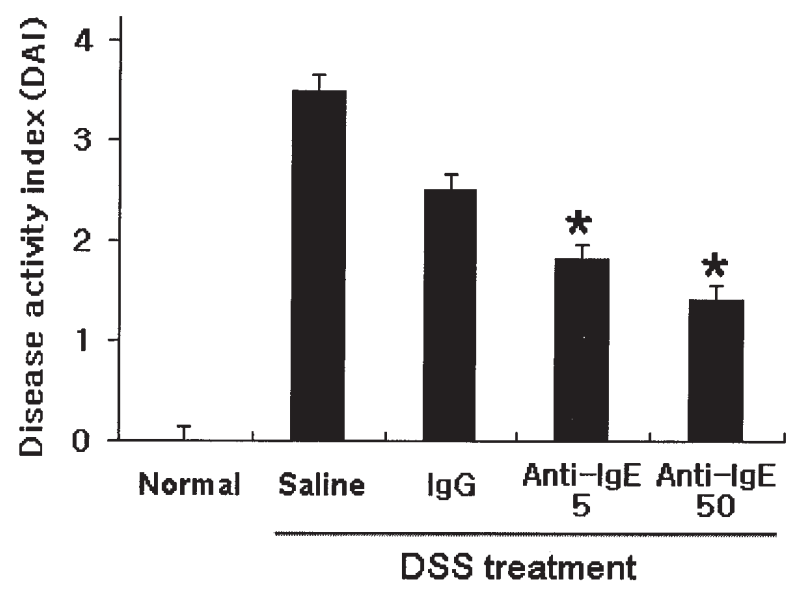

Figure 2. Effect of anti-IgE antibody on DAI in DSS-induced colitis. Colitis was induced by oral administration of DSS (5\%) for 7 days and anti-IgE antibody (R35-92) was injected subcutaneously at two different doses, $5 \mu \mathrm{g} / \mathrm{kg}$ and $50 \mu \mathrm{g} / \mathrm{kg}$ body weight. $\operatorname{IgG}(50 \mu \mathrm{g} / \mathrm{kg})$ and saline were used as comparative controls. DAI was calculated at day 7 after DSS treatment as described in Materials and methods. Data are expressed as the mean \pm SEM ( ${ }^{*} \mathrm{p}<0.05$ vs. DSS plus saline).

against TNF- $\alpha$ and COX-2 for $12 \mathrm{~h}$ at $4^{\circ} \mathrm{C}$. After washing the membranes in $1 \mathrm{X}$ PBS containing $0.1 \%$ Tween-20, the immunoblots were incubated with the goat anti-mouse IgGhorseradish peroxidase (HRP) conjugate, at a 1:20,000 dilution for $45 \mathrm{~min}$. Finally, the epitopes on the proteins recognized by the specific antibody were visualized using an enhanced chemiluminescence detection kit (Amersham Pharmacia Biotech).

Serum IgE measurements. IgE levels in serum were measured using a commercial ELISA kit (Bethyl Laboratories,
Montgomery, TX) according to the manufacturer's instructions. Briefly, microtiter plates were coated overnight at $4^{\circ} \mathrm{C}$ with rat anti-mouse $\operatorname{IgE}$ diluted in phosphate-buffered saline (PBS) and then blocked with ELISA buffer containing $50 \mathrm{mM}$ Tris- $\mathrm{HCl}$ ( $\mathrm{pH} 7.2$ ), $0.5 \%$ bovine serum albumin, $2 \mathrm{mM}$ EDTA, $136.9 \mathrm{mM} \mathrm{NaCl}, 0.05 \%$ Tween-20 for $1 \mathrm{~h}$ at room temperature. Serum samples diluted in ELISA buffer were added to the plates and incubated overnight at $4^{\circ} \mathrm{C}$. After washing, the plates were incubated with $1 \mu \mathrm{g} / \mathrm{ml}$ second biotinylated antibody and streptavidin-peroxidase diluted in ELISA buffer for $1 \mathrm{~h}$. Color development was performed with o-phenylene-diamine substrate $(0.4 \mathrm{mg} / \mathrm{ml})$ and $0.04 \%$ $\mathrm{H}_{2} \mathrm{O}_{2}$ in PBS and the reactions were stopped by adding $4 \mathrm{M}$ $\mathrm{H}_{2} \mathrm{SO}_{4}$. The optical density was measured at $492 \mathrm{~nm}$ using a microplate reader.

Statistical analysis. All values are described as the mean \pm SEM. Statistical significance was determined using the Student's t-test to express the difference between the two groups. All p-values $<0.05$ were considered to reflect a statistically significant difference.

\section{Results}

Anti-IgE antibody inhibits the clinical signs in DSS-induced colitis. We examined the inhibitory effects of non-anaphylactogenic anti-IgE antibody (R35-92) on the state of intestines in DSS-induced experimental colitis. Prior to DSS treatment of the mice, the anti-IgE antibody was subcutaneously injected only once at two doses, $5 \mu \mathrm{g} / \mathrm{kg}$ and $50 \mu \mathrm{g} / \mathrm{kg}$ body weight of the mice. $\operatorname{IgG}(50 \mu \mathrm{g} / \mathrm{kg})$ and saline were injected as control by the same route. On day 7 after 5\% DSS treatment, the physical signs (weight loss, colon length, diarrhea, and occult/gross bleeding) were observed separately and the DAI

\section{Normal}

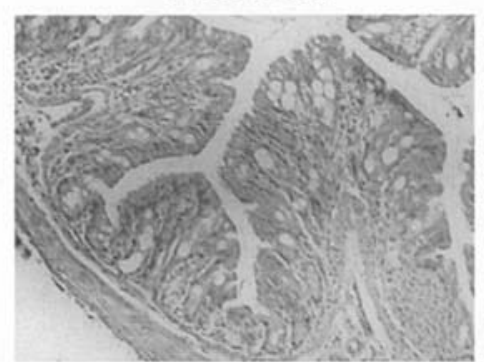

\section{DSS+Saline}

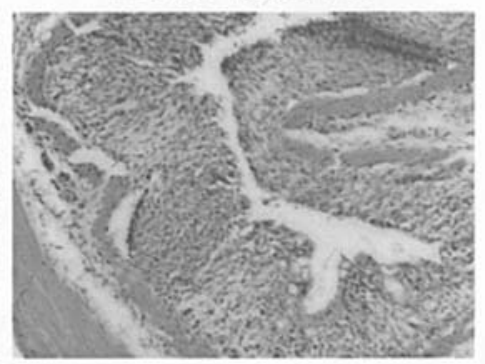

DSS+IgG

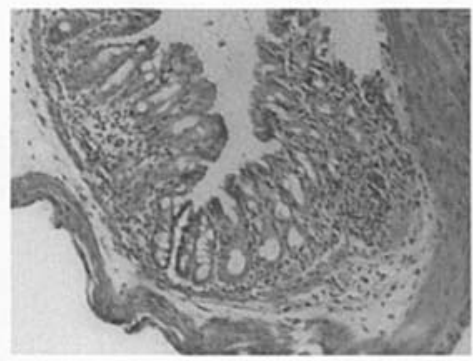

DSS+anti-IgE (5)

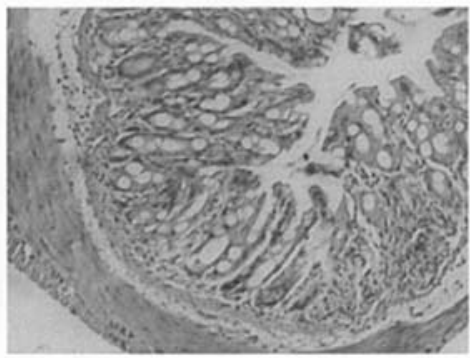

DSS+anti-IgE (50)

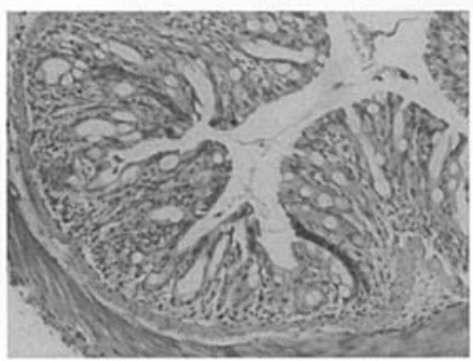

Figure 3. Histopathologic feature of colon tissues in DSS-induced colitis. Colon specimens were paraffin embedded and stained with hematoxylin and eosin (magnification, x100). DSS treatment for 7 days resulted in crypt loss, surface epithelial loss, and infiltration of inflammatory cells in the mucosa. Injection of anti-IgE antibody $(5 \mu \mathrm{g} / \mathrm{kg}$ or $50 \mu \mathrm{g} / \mathrm{kg})$ reduced significantly the histological damage of the colon wall structure by DSS treatment compared to that of saline. 

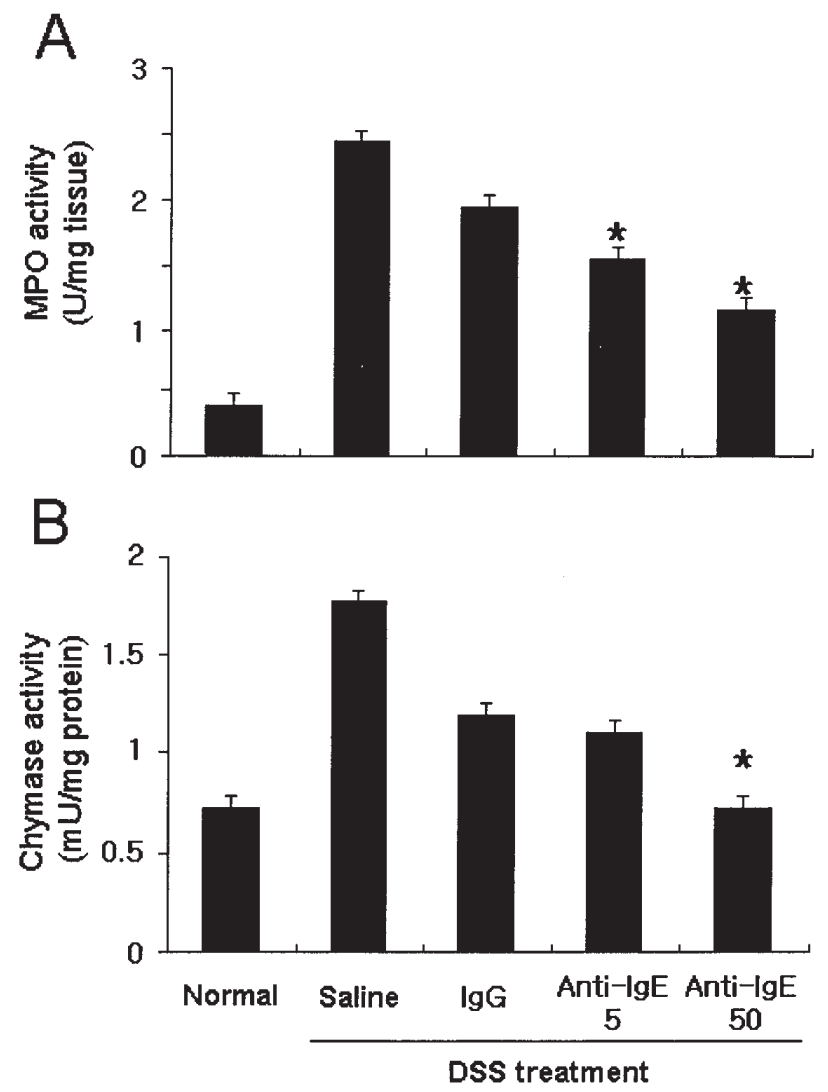

Figure 4. Effect of anti-IgE antibody on the activity of MPO (A) and chymase (B) in DSS-induced colitis. On day 0 of DSS treatment, anti-IgE antibody (R35-92) was injected subcutaneously at two different doses, $5 \mu \mathrm{g} /$ $\mathrm{kg}$ and $50 \mu \mathrm{g} / \mathrm{kg}$ body weight. IgG $(50 \mu \mathrm{g} / \mathrm{kg})$ and saline were used as comparative controls. The activities of MPO and chymase in the colon tissue were determined at day 7 after DSS treatment as described in Materials and methods. Data are expressed as the mean \pm SEM $\left({ }^{*} \mathrm{p}<0.05\right.$ vs. DSS plus saline).

was calculated as shown in Table I. All mice treated with 5\% DSS for 7 days survived and showed a significant loss of body weight (Fig. 1A) and colon shortening (Fig. 1B) compared to the normal control group. In contrast, mice injected with anti-IgE antibody (both $5 \mu \mathrm{g} / \mathrm{kg}$ and $50 \mu \mathrm{g} / \mathrm{kg}$ ) showed a significant attenuation of body weight loss and colon shortening caused by DSS treatment as assessed by body weight loss and colon shortening. In addition, the DAI was also remarkably inhibited in the groups injected with the anti-IgE antibody (5 $\mu \mathrm{g} / \mathrm{kg}$ and $50 \mu \mathrm{g} / \mathrm{kg}$ ) (Fig. 2) compared to the control groups injected with saline. Unexpectedly, control IgG administration slightly attenuated the DAI caused by DSS treatment.

Next, we observed the histological damage of the colon on day 7 after DSS treatment. Sections of distal colon tissue were stained by hematoxylin and eosin. As shown in Fig. 3B, DSS treatment revealed lesions of the colon consisting of multifocal areas, mucosal erosion, a loss of epithelial and goblet cells, the shortening and collapse of crypts, and submucosal edema. Administration of $5 \mu \mathrm{g} / \mathrm{kg}$ or $50 \mu \mathrm{g} / \mathrm{kg}$ of the anti-IgE antibody significantly reduced the lesions of the colon in DSS-induced colitis compared to that of saline or control IgG. Especially, the high concentration $(50 \mu \mathrm{g} / \mathrm{kg})$ of anti-IgE antibody remarkably showed protective and healing effects (Fig. 3). These results indicate that non-anaphy-

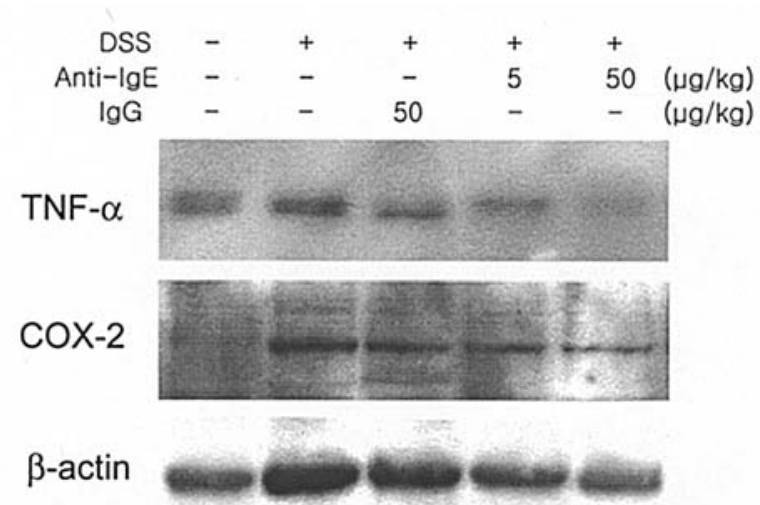

Figure 5. Effect of anti-IgE antibody on the expression of TNF- $\alpha$ and COX-2 in DSS-induced colitis. At day 0 of DSS treatment, anti-IgE antibody (R35-92) was injected subcutaneously at two different doses, $5 \mu \mathrm{g} / \mathrm{kg}$ and $50 \mu \mathrm{g} / \mathrm{kg}$ body weight. $\operatorname{IgG}(50 \mu \mathrm{g} / \mathrm{kg})$ and saline were used as comparative controls. The analysis of TNF- $\alpha$ and COX-2 protein was performed on day 7 after DSS treatment as described in Materials and methods.

lactogenic anti-IgE antibody may effectively inhibit the development of colitis caused by DSS.

Anti-IgE antibody reduces myeloperoxidase (MPO) and chymase activity in DSS-induced colitis. MPO activity was closely correlated with clinical, macroscopic, and histological grading of inflammation in the experimental groups. MPO activity was remarkably increased in the intestinal tissue of DSS-treated mice compared to that of normal control mice (19). Administration of 5 and $50 \mu \mathrm{g} / \mathrm{kg}$ of anti-IgE antibody induced a $38 \%$ and a $54 \%$ decrease in MPO activity, respectively, in DSS-induced colitis, whereas the saline and control IgG groups exhibited no significant reduction in the development of DSS-induced colitis (Fig. 4A). On the other hand, the increased chymase activity in the DDS-treated colon was also significantly reduced (Fig. 4B) by anti-IgE antibody administration. These results strongly indicate that the recruitment of leukocytes, neutrophils and mast cells, could be reduced by a mechanism for the protective effects of anti-IgE antibody.

Anti-IgE antibody inhibits the expression of inflammation inducing factors in DSS-induced colitis. IgE response plays an important role in the release of inflammatory mediators in helminth infections and allergic diseases $(11,14)$. We thus examined the inhibitory effects of the anti- $\operatorname{IgE}$ antibody on the expression of TNF- $\alpha$ and COX-2, which are synthetic enzymes for prostagrandins, in UC tissue. The colon tissue was excised on day 7 after DSS treatment. TNF- $\alpha$ and COX2 expression was detected by Western blot analysis using their specific antibodies. In the DSS-induced colitis model, the expression of TNF- $\alpha$ and COX-2 was increased in the intestinal tissue compared to that in the normal tissue. As the anti-IgE antibody was subcutaneously injected once on day 0 , the increased expression of TNF- $\alpha$ and COX-2 was significantly reduced in the colon tissue, whereas both the saline and control $\mathrm{IgG}$ did not cause a remarkable decrease in their expression. Especially, the inhibitory effect of anti-IgE antibody was dependent on the injected dose (Fig. 5). Next, 


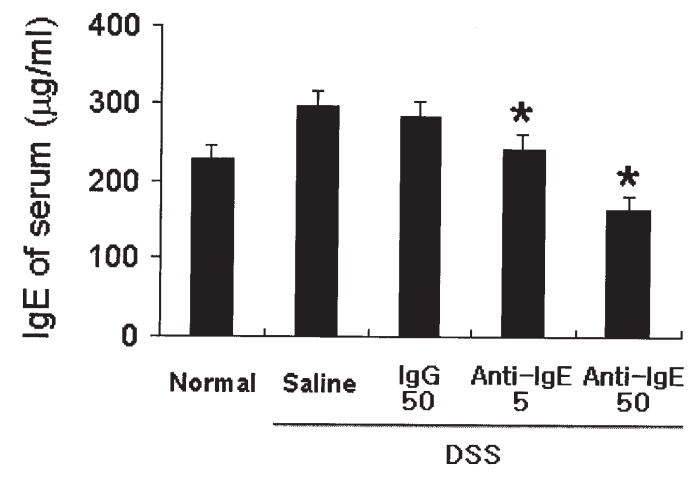

Figure 6. Effect of anti-IgE antibody on IgE levels of serum in DSS-induced colitis. On day 0 of DSS treatment, anti-IgE antibody (R35-92) was injected subcutaneously at two different doses, $5 \mu \mathrm{g} / \mathrm{kg}$ and $50 \mu \mathrm{g} / \mathrm{kg}$ body weight. $\operatorname{IgG}(50 \mu \mathrm{g} / \mathrm{kg})$ and saline were used as comparative controls. IgE levels of serum were determined on day 4 after DSS treatment as described in Materials and methods. Data are expressed as the mean \pm SEM $\left({ }^{*} \mathrm{p}<0.05\right.$ vs. DSS plus saline).

as the anti-IgE antibody (R35-92) has been known to prevent IgE synthesis and $\mathrm{B}$ cell activation through ligation of the $\operatorname{IgE}$-IgE receptor $(15,16)$, we determined the IgE levels in serum on day 4 after DSS treatment with and without antiIgE administration. DSS treatment slightly elevated the $\operatorname{IgE}$ level in serum $(296 \pm 27 \mathrm{ng} / \mathrm{ml})$ compared to that $(226 \pm 15 \mathrm{ng} / \mathrm{ml})$ of normal mice. Thereafter, the injections of 5 and $50 \mu \mathrm{g} / \mathrm{kg}$ of the anti-IgE antibody resulted in an approximate 19\% and $45 \%$ reduction of IgE levels in serum in DSS-treated mice, respectively, whereas the injection of control IgG induced no significant difference (Fig. 6). These results implicate that the non-anaphylactogenic anti-IgE antibody (R35-92) may attenuate the manifestation of IgE-dependent colitis by blocking IgE-effector functions.

\section{Discussion}

In this study, we examined the effect of the nonanaphylactogenic anti-IgE antibody ameliorating all the considered inflammatory symptoms in a DSS-induced colitis murine model. The anti-IgE antibody significantly reduced most of the clinical signs, such as body weight loss, colon shortening, rectal bleeding, and diarrhea of colitis. Furthermore, the anti-IgE antibody significantly suppressed the activities of chymase and MPO and the expression of inflammatory markers such as $\mathrm{TNF}-\alpha$ and $\mathrm{COX}-2$.

Intestinal mast cells are thought to contribute to the mucosal inflammation in ulcerative colitis and Crohn's disease through release of inflammatory mediators. Mast cells are found within all layers of the gut wall throughout the gastrointestinal tract. Since mast cells are the major IgEeffector cells expressing a high affinity for $\operatorname{IgE}$ receptors FceRI (22), the activation of mast cells releases a number of biologically active substances to influence gut function, including fluid and electrolyte transport (23-25). Thus, the evidence that mast cells may regulate gut function has been implicated in the pathogenesis of a number of gastrointestinal diseases including IBD, coeliac disease, food allergy, and systemic mastocytosis (26). Several studies have shown that the number of mast cells was increased in IBD intestines $(27,28)$ and the enhanced levels of mast cell mediator were observed in the gut lumen of patients with active UC and CD $(29,30)$. In addition, enhanced release of histamine and eicosanoids has also been described in actively inflamed IBD tissue after isolated intestinal mast cells were stimulated by crosslinking IgE receptors. The activation of isolated intestinal mast cells by crosslinking $\operatorname{IgE}$ receptors on the surface resulted in enhanced release of histamine and eicosanoids as well as a chloride secretory response (31). In the present study, we also observed that the non-anaphylactogenic anti-IgE treatment could reduce the expression of mast cell-mediated inflammatory factors in DSS-induced colitis, indicating that the intestinal mast cell activation through FceRI may play a role in the pathogenesis of UC.

High affinity $\operatorname{IgE}$ receptor, FceRI, is expressed not only in mast cells and basophils but also in monocytes, Langerhans cells, eosinophils, neutrophils and platelets in humans $(22,32)$, suggesting that the onset of colitis in humans is not only associated with mast cells but also with Fc $\gamma$ RI expressing cells. Evidence of the above has been documented in an animal study showing that the inflammatory signs in 2,4,6trinitrobenzene sulfonic acid (TNBS)-induced acute colitis were completely protected in FceRI-deficient mice (33) and the release of IL-8 through the engagement of FceRI in human neutrophils was inhibited by anti-IgE treatment (32). Furthermore, FceRI expression of eosinophils and macrophages may also contribute to the increased pathology by affecting the intestinal barrier. The absence of IL-4, which is a cytokine regulating the synthesis of $\operatorname{IgE}$, also showed the inhibition of TNBS-induced colitis (34). Collectively, these reports provide critical evidence that all FceRI-expressing cells may play a role in the inflammation of colitis through an IgE-dependent activation mechanism, suggesting that the non-anaphylactogenic anti-IgE may extensively inhibit the interaction of $\operatorname{IgE}$ to all of the FceRI-expressing cells as well as mast cells in the human intestine.

Unexpectedly, we observed that treatment of $\operatorname{IgG}$ used as a control could inhibit the development of DSS-induced colitis, even though its effect was lower than that of anti-IgE. Our results from a previous report showed that homologous $\mathrm{IgG}$ reduced the development of DSS-induced colitis via delivering its nonspecific inhibitory signaling by binding to their Fc receptors $(\mathrm{Fc} \gamma \mathrm{R})(35)$. Fc $\gamma \mathrm{RIIb}$, which is a low-affinity receptor for $\mathrm{IgG}$, is expressed in various immune cells including B cells, T cells, mast cells, and macrophages. As Fc $\gamma$ RIIb has an immunoreceptor tyrosine-based inhibition motif (ITIM) in the intracytoplasmic domain, the engagement of Fc $\gamma$ RIIb with IgG negatively results in the regulation of cell activation, such as BCR-mediated B cell activation, TCR-mediated T cell activation, and FceRI-mediated mast cell activation (36). Thereby, IgG might provide the inhibitory signals in Fc $\gamma$ RIIb-expressing cells to downregulate IgE synthesis and release of mediators. Based on this hypothesis, the inhibitory effect of anti IgE in DSS-induced colitis might be due, not only to the blockage of $\mathrm{IgE}$ response, but also to the IgG ligation to Fc $\gamma$ RIIb.

So far, many processes in the inflammatory cascade, such as antigen presentation, $\mathrm{T}$ cell activation, overproduction of pro-inflammatory cytokines, and migration of inflammatory 
cells, were investigated as targets to treat IBD. In previous studies, TNF- $\alpha$ was a useful therapeutic target to blockade effector signals. The treatment of anti-TNF- $\alpha$ antibody inhibited the induction of many cytokines and adhesion molecules in chronic IBD (8). However, the strategy of antiTNF- $\alpha$ might be restricted to neutralize TNF- $\alpha$ released by activated cells, particularly mast cells, but not by other mediators, including tryptase, chymase, and histamine, in contrast with that of anti-IgE.

In conclusion, we observed that treatment with the antiIgE antibody may significantly reduce the clinical signs and the expression of inflammatory mediators in a colitis model caused by DSS treatment. These results suggest that the nonanaphylactogenic anti-IgE antibody may be a useful therapeutic agent for ulcerative colitis. However, anti-IgE therapy is limited to IgE-dependent responses only, even though the additional inhibitory effect might be derived from the engagement of Fc $\gamma$ RIIb on the surface of effector cells. Thus, the therapeutic agents for IgE-independent colitis remain to be studied.

\section{Acknowledgments}

This work was supported by grants from Wonkwang University in 2005.

\section{References}

1. Fiocchi C: Inflammatory bowel disease; etiology and pathogenesis. Gastroenterology 115: 182-205, 1998.

2. Hyams JS: Inflammatory bowel disease. Pediatr Rev 21: 291-295, 2000.

3. Danese S, Sans M and Fiocchi C: Inflammatory bowel disease; the role of environmental factors. Autoimmun Rev 3: 394-400, 2004.

4. Hendrickson BA, Gokhale R and Cho JH: Clinical aspects and pathophysiology of inflammatory bowel disease. Clin Microbiol Rev 15: 79-94, 2002.

5. Blumberg RS, Saubermann LJ and Strober W: Animal models of mucosal inflammation and their relation to human inflammatory bowel disease. Curr Opin Immunol 11: 648-656, 1999.

6. Shetty K, Rybicki L, Brzezinski A, Carey WD and Lashner BA: The risk for cancer or dysplasia in ulcerative colitis patients with primary sclerosing cholangitis. Am J Gastroenterol 94: 1643-1649, 1999.

7. Baert F, Vermeire S, Noman M, Van Assche G, D'Haens G and Rutgeerts P: Management of ulcerative colitis and Crohn's disease. Acta Clin Belg 59: 304-314, 2004.

8. Cuzzocrea S: Emerging biotherapies for inflammatory bowel disease. Expert Opin Emerg Drugs 8: 339-347, 2003.

9. Nolte H, Spjeldnaes N, Kruse A and Windelborg B: Histamine release from gut mast cells from patients with inflammatory bowel diseases. Gut 31: 791-794, 1990.

10. Raithel M, Winterkamp S, Pacurar A, Ulrich P, Hochberger J and Hahn EG: Release of mast cell tryptase from human colorectal mucosa in inflammatory bowel disease. Scand J Gastroenterol 36: 174-179, 2001.

11. Bischoff SC, Lorentz A, Schwengberg S, Weier G, Raab R and Manns MP: Mast cells are an important cellular source of tumour necrosis factor alpha in human intestinal tissue. Gut 44 : 643-652, 1999.

12. Kim JA, Choi SC, Yun KJ, et al: Expression of proteaseactivated receptor 2 in ulcerative colitis. Inflamm Bowel Dis 9: 224-229, 2003.

13. Ceyhan BB, Karakurt S, Cevik H and Sungur M: Bronchial hyperreactivity and allergic status in inflammatory bowel disease. Respiration 70: 60-66, 2003.

14. Negrao-Correa D: Importance of immunoglobulin E (IgE) in the protective mechanism against gastrointestinal nematode infection: looking at the intestinal mucosae. Rev Inst Med Trop Sao Paulo 43: 291-299, 2001.
15. Stampfli MR, Miescher S, Aebischer I, Zurcher AW and Stadler BM: Inhibition of human IgE synthesis by anti-IgE antibodies requires divalent recognition. Eur J Immunol 24: 2161-2167, 1994

16. Casale TB, Bernstein IL, Busse WW, et al: Use of an anti-IgE humanized monoclonal antibody in ragweed-induced allergic rhinitis. J Allergy Clin Immunol 100: 110-121, 1997.

17. Okayasu I, Hatakeyama S, Yamada M, et al. Novel method in the induction of reliable experimental acute and chronic ulcerative colitis in mice. Gastroenterology 98: 694-702. 1990.

18. Murthy SN, Cooper HS, Shim H, Shah RS, Ibarahim SA and Sedergran DJ: Treatment of dextran sulfate sodium-induced murine colitis by intracolonic cyclosporin. Dig Dis Sci 38: 1722-1734, 1993.

19. Krawisz JE, Sharon P and Stenson WF: Quantitative assay for acute intestinal inflammation based on myeloperoxidase activity. Assessment of inflammation in rat and hamster models. Gastroenterology 87: 1344-1350, 1984.

20. Kakizoe E, Li SH, Kobayashi Y, Nishikori Y, Dekio S and Okunishi H: Increases in mast cells and chymase in fibroproliferative paws of collagen-induced arthritic mice. Inflamm Res 48: 318-324, 1999.

21. Schechter NM, Slavin D, Fetter RD, Lazarus GS and Fräki JE: Purification and identification of two serine class proteinases from dog mast cells biochemically and immunologically similar to human proteinases tryptase and chymase. Arch Biochem Biophys 262: 232-243, 1988.

22. Kinet JP: The high-affinity IgE receptor (Fc epsilon RI): from physiology to pathology. Annu Rev Immunol 17: 931-972, 1999.

23. Crowe SE, Sestini $\mathrm{P}$ and Perdue $\mathrm{MH}$ : Allergic reactions of rat jejunal mucosa. Ion transport responses to luminal antigen and inflammatory mediators. Gastroenterology 99: 74-82, 1990.

24. Bern MJ, Sturbaum CW, Karaylacin SS, Berschneider HM, Wachsman JT and Powell DW: Immune system control of rat and rabbit colonic electrolyte transport: role of prostaglandins and enteric nervous system. J Clin Invest 83: 1810-1820, 1989.

25. Stack WA, Keely SJ, O'Donoghue DP and Baird AW: Immune regulation of human colonic electrolyte transport in vitro. Gut 36: 395-400, 1995.

26. Crowe SE and Perdue MH: Gastrointestinal food hypersensitivity: basic mechanisms of pathophysiology. Gastroenterology 103: 1075-1095, 1992.

27. Sommers SC: Mast cells and Paneth cells in ulcerative colitis. Gastroenterology 51: 841-850, 1966.

28. King T, Biddle W, Bhatia P, Moore J and Miner PB: Colonic mucosal mast cell distribution at line of demarcation of active ulcerative colitis. Dig Dis Sci 37: 490-495, 1992.

29. Rampton DS, Murdoch RD and Sladen GE: Rectal mucosal histamine release in ulcerative colitis. Clin Sci 59: 389-391, 1980.

30. Knutson L, Ahrenstedt O, Odlind B and Hallgren R: The jejunal secretion of histamine is increased in active Crohn's disease. Gastroenterology 98: 849-854, 1990.

31. Fox CC, Lazenby AJ, Moore WC, Yardley JH, Bayless TM and Lichtenstein LM: Enhancement of human intestinal mast cell mediator release in active ulcerative colitis. Gastroenterology 99: 119-124, 1990.

32. Gounni AS, Lamkhioued B, Koussih L, Ra C, Renzi PM and Hamid Q: Human neutrophils express the high-affinity receptor for immunoglobulin E (Fc epsilon RI): role in asthma. FASEB J 15: 940-949, 2001.

33. Dombrowicz D, Nutten S, Desreumaux P, et al: Role of the high affinity immunoglobulin $\mathrm{E}$ receptor in bacterial translocation and intestinal inflammation. J Exp Med 193: 25-34, 2001.

34. Dohi T, Fujihashi K, Rennert PD, Iwatani K, Kiyono H and McGhee JR: Hapten-induced colitis is associated with colonic patch hypertrophy and T helper cell 2-type responses. J Exp Med 189: 1169-1180, 1999.

35. Ravetch J and Bolland VS: IgG Fc receptors. Annu Rev Immunol 19: 275-290, 2001.

36. Daëron M, Latour S, Malbec O, Espinosa E, Pina P, Pasmans S and Fridman WH: The same tyrosine-based inhibition motif, in the intracytoplasmic domain of Fc $\gamma$ RIIB, regulates negatively BCR-, TCR-, and FcR-dependent cell activation. Immunity 3: 635-646, 1995. 